\title{
Sphenoid Sinus Schneiderian Papilloma
}

National Cancer Institute

\section{Source}

National Cancer Institute. Sphenoid Sinus Schneiderian Papilloma. NCI Thesaurus. Code C6838.

A papilloma that arises from the ciliated respiratory mucosa that lines the sphenoid sinus. It is classified as inverted papilloma and oncocytic papilloma. 